\title{
PENGARUH INFLASI, BI RATE, KURS RUPIAH, DAN \\ HARGA EMAS DUNIA TERHADAP INDEKS HARGA SAHAM SEKTOR PERTAMBANGAN DI INDONESIA
}

\author{
Riana Rismala ${ }^{1}$ \\ Elwisam $^{2}$ \\ ${ }^{1,2}$ Fakultas Ekonomi dan Bisnis Universitas Nasional \\ Email: rianarismala10@gmail.com ${ }^{1}$, wisamkrimuk@yahoo.com²
}

\begin{abstract}
ABSTRAK
Penelitian ini bertujuan untuk menganalisis pengaruh inflasi, BI Rate, kurs rupiah, dan harga emas dunia terhadap indeks harga saham sektor pertambangan di Indonesia. Penelitian dilakukan menggunakan data time series pada periode Januari 2009 - Desember 2015. Dengan menggunakan regresi linier berganda, hasil penelitian menunjukkan bahwa: (1) inflasi berpengaruh positif dan signifikan terhadap indeks harga saham sektor pertambangan; (2) BI rate tidak berpengaruh signifikan terhadap indeks harga saham sektor pertambangan; (3) kurs rupiah berpengaruh negatif dan signifikan terhadap indeks harga saham sektor pertambangan; dan (4) harga emas dunia berpengaruh positif dan signifikan terhadap indeks harga saham sektor pertambangan.
\end{abstract}

Kata kunci: Indeks harga saham sektor pertambangan, inflasi, BI rate, kurs rupiah, harga emas dunia

\section{ABSTRACT}

This study aims to analyze the effect of inflation, BI Rate, rupiah exchange rate, and world gold prices on the stock price index of the mining sector in Indonesia. The study was conducted using time series data in the period January 2009 - December 2015. Using multiple linear regression, the results showed that: (1) inflation has a positive and significant effect on the stock price index of the mining sector; (2) BI rate does not significantly influence the stock price index of the mining sector; (3) the rupiah exchange rate has a negative and significant effect on the stock price index of the mining sector; and (4) world gold price has a positive and significant effect on the stock price index of the mining sector.

Keywords: Stock price index of the mining sector, inflation, BI rate, rupiah exchange rate, world gold price

\section{PENDAHULUAN}

Perkembangan pasar modal di suatu negara pada dasarnya tidak terlepas dari perkembangan perekonomian di negara tersebut. Dalam hal ini, tingginya pertumbuhan perekonomian dan baiknya kondisi bisnis di suatu negara diharapkan mampu untuk meningkatkan harga saham. Selain berperan dalam menunjang perekonomian di suatu negara, secara makro, pasar modal juga dapat berperan sebagai sarana bagi pemerataan 
pendapatan yang menghubungkan antara pihak yang kelebihan dana dengan pihak yang membutuhkan dana. Dengan adanya pasar modal, perusahaan dapat memperoleh dana yang dibutuhkannya untuk kepentingan operasional dan pengembangtannya, sementara investor dapat memperoleh keuntungan dari perusahaan yang bersangkutan meskipun tidak menjadi pendiri ataupun pengelola perusahaan tersebut.

Dalam kurun waktu 10 tahun terakhir, investasi di sektor pertambangan menjadi salah satu pilihan yang paling diminati oleh investor. Hal tersebut dikarenakan sektor pertambangan merupakan sektor yang semakin strategis bagi Indonesia mengingat banyaknya sumber tambang yang dimiliki Indonesia. Sektor pertambangan itu sendiri merupakan salah satu komoditas utama dalam perekonomian modern yang terutama digerakkan oleh subsektor energi, yaitu minyak dan batu bara. Bersama dengan emas, minyak dan batu bara merupakan sumber energi utama bagi sebagian besar proses produksi dan kegiatan perekonomian di dunia.

Selama periode 2009-2015, indeks harga saham sektor pertambangan terus mengalami penurunan di setiap tahunnya hingga mencapai titik terendah di tahun 2015, yakni pada nilai sebesar 811 sebagaimana yang ditunjukkan pada gambar 1. Pergerakan indeks harga saham tersebut dapat mencerminkan adanya penurunan aktivitas transaksi jual-beli saham di sektor pertambangan. Padahal, sebelumnya telah dijelaskan bahwa saham di sektor pertambangan merupakan saham yang memiliki daya tarik kuat. Dalam hal ini, berbagai variabel makro dapat menjadi faktor yang melatar belakangi terjadinya penurunan indeks harga saham di sektor pertambangan tersebut.

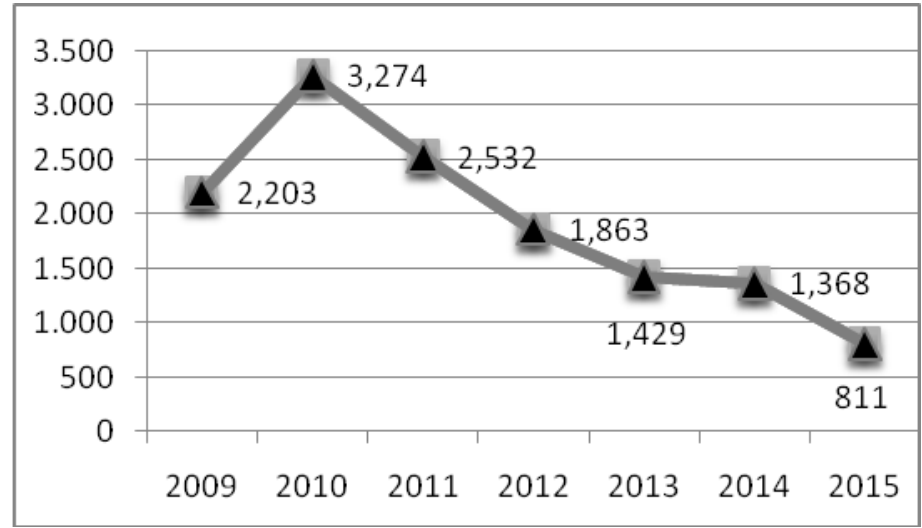

(Sumber: BEI, 2017)

\section{Gambar 1. Pergerakan Indeks Harga Saham Sektor Pertambangan di Indonesia Periode 2009-2015}


Salah satu variabel makroekonomi yang dapat mempengaruhi indeks harga saham adalah tingkat inflasi. Dalam hal ini, tingkat inflasi yang tinggi mencerminkan adanya kenaikan harga barang-barang secara umum yang menyebabkan terjadinya penurunan daya beli. Hal tersebut akan menimbulkan terjadinya penurunan minat investor dalam berinvestasi, sehingga akan menyebabkan harga saham perusahaan mengalami penurunan (Riantani dan Tambunan, 2013). Pendapat tersebut diperkuat oleh hasil penelitian yang dilakukan oleh Ginting, dkk. (2016) yang berhasil membuktikan bahwa inflasi berpengaruh negatif dan signifikan terhadap harga saham pada sektor perbankan. Akan tetapi, hasil penelitian yang dilakukan oleh Taqiyuddin, dkk. (2012) justru menunjukkan bahwa inflasi berpengaruh positif dan signifikan terhadap indeks harga saham, sementara Harsono dan Worokinasih (2018) justru tidak menemukan adanya pengaruh inflasi yang signifikan terhadap indeks harga saham.

Variabel lain yang dapat mempengaruhi indeks harga saham adalah BI rate. Menurut Tandelilin (2010), perubahan BI Rate mampu mempengaruhi indeks harga saham secara terbalik dengan asumsi cateris paribus. Secara teori, kenaikan BI Rate akan membuat suku bunga bank menjadi naik, sehingga menimbulkan terjadinya peralihan dana dari pasar modal ke perbankan. Akibatnya, indeks harga saham pun akan mengalami penurunan. Pengaruh negatif dan signifikan dari BI Rate tersebut terhadap indeks harga saham telah dibuktikan oleh Jannah dan Nurfauziah (2018). Hal tersebut berbeda dengan hasil penelitian yang dilakukan oleh Anisa dan Darmawan (2016) yang menunjukkan bahwa tingkat suku bunga berpengaruh positif dan signifikan terhadap indeks harga saham sektor pertambangan. Hasil penelitian yang dilakukan oleh Wongkar, dkk. (2018) bahkan justru menunjukkan bahwa BI rate tidak berpengaruh signifikan terhadap indeks harga saham.

Kurs rupiah juga dapat menjadi salah satu faktor yang mampu mempengaruhi indeks harga saham. Jannah dan Nurfauziah (2018) membuktikan bahwa nilai tukar rupiah berpengaruh positif dan signifikan terhadap indeks harga saham. Keduanya menjelaskan bahwa depresiasi nilai tukar rupiah dapat memperkuat indeks harga saham apabila saham dari perusahaan-perusahaan yang tergabung dalam indeks tersebut didominasi oleh saham perusahaan yang berorientasi ekspor. Dalam hal ini, depresiasi nilai tukar rupiah akan membuat barang ekspor menjadi lebih murah dari perspektif luar negeri sehingga akan menaikkan permintaan dan pada akhirnya menyebabkan terjadinya kenaikan pada indeks 
harga saham. Hal tersebut berbanding terbalik dengan hasil penelitian yang dilakukan oleh Harsono dan Worokinasih (2018) yang menunjukkan bahwa kurs rupiah berpengaruh negatif dan signifikan terhadap indeks harga saham. Akan tetapi, Anisa dan Darmawan (2018) justru tidak menemukan adanya pengaruh nilai tukar rupiah yang signifikan terhadap indeks harga saham sektor pertambangan.

Indeks harga saham juga dapat dipengaruhi oleh variabel harga emas dunia. Hal tersebut dikarenakan emas itu sendiri merupakan salah satu komoditas utama yang ditawarkan oleh perusahaan-perusahaan yang bergerak di sektor pertambangan. Pengaruh positif yang signifikan dari harga emas dunia terhadap indeks harga saham tersebut juga telah berhasil dibuktikan oleh Gumilang, dkk. (2014). Akan tetapi, hasil penelitian yang dilakukan oleh Cumando (2014) justru menunjukkan bahwa harga emas dunia berpengaruh negatif dan signifikan terhadap harga saham dari perusahaan di sektor pertambangan.

Berdasarkan uraian di atas, ditemukan adanya research gap yang perlu dianalisis kembali. Oleh karena itu, dilakukanlah penelitian ini yang bertujuan untuk menganalisis pengaruh inflasi, BI rate, kurs rupiah, dan harga emas dunia terhadap indeks harga saham sektor pertambangan di Indonesia yang dalam hal ini menggunakan data pada periode 2009-2015, yaitu periode dimana indeks harga saham sektor pertambangan menunjukkan adanya trend penurunan.

\section{TINJAUAN PUSTAKA}

\section{Indeks Harga Saham Sektoral}

Indeks harga saham merupakan suatu indikator yang mencerminkan pergerakan harga saham. Pergerakan indeks itu sendiri akan mencerminkan kondisi pasar saat sedang aktif ataupun lesu (Darmadji dan Fakhruddin, 2011). Dalam dunia pasar modal, indeks atas saham merupakan portofolio imaginer yang mengukur perubahan harga dari suatu ataupun sebagian pasar. Dengan melihat pergerakan indeks saham, investor dapat mengetahui kinerja harga umum dari saham-saham yang dimilikinya (BEI, 2017).

Indeks sektoral dapat didefinisikan sebagai indeks yang mengukur kinerja harga atas seluruh saham dari setiap sektor industri yang termasuk ke dalam klasifikasi Jakarta Stock Industrial Classification (BEI, 2018). Dengan demikian, indeks harga saham sektor pertambangan merupakan indeks yang mengukur kinerja harga atas seluruh saham yang 
diklasifikasikan ke dalam sektor pertambangan.

Menurut Darmadji dan Fakhruddin (2011), suatu indeks di pasar modal diharapkan memiliki lima fungsi, yaitu: (1) sebagai indikator atas tren pasar; (2) sebagai indikator atas tingkat keuntungan; (3) sebagai benchmark atas performa dari suatu portofolio; (4) memfasilitasi pembentukan portofolio dengan strategi pasif; dan (5) memfasilitasi pengembangan produk derivatif.

\section{Inflasi}

Menurut Tandelilin (2010:342), inflasi adalah kecenderungan terjadinya kenaikan harga produk secara menyeluruh yang menyebabkan terjadinya penurunan daya beli uang. Adapun Putong (2013:276) mendefinisikan inflasi sebagai kenaikan harga komoditas yang disebabkan oleh ketidak sinkronan antara program sistem pengadaan komoditas dengan tingkat pendapatan masyarakat di suatu negara.

Berdasarkan penyebabnya, Boediono (2013) membedakan inflasi ke dalam dua kategori berikut.

1. Demand Pull Inflation, yaitu inflasi yang disebabkan oleh terlalu kuat atau terlalu banyaknya permintaan masyarakat terhadap berbagai barang, sementara penawaran tetap.

2. Cost Push Inflation, yaitu inflasi yang disebabkan oleh penurunan produksi akibat kenaikan biaya produksi yang dapat dipicu oleh inefisiensi perusahaan, turunnya nilai kurs, naiknya harga bahan baku industri, tuntutan yang kuat dari serikat buruh atas kenaikan upah, dan sebagainya.

Adapun berdasarkan asalnya, Boediono (2013) membedakan inflasi ke dalam dua kategori berikut.

1. Inflasi yang berasal dari dalam negeri (domestic inflation), yaitu inflasi yang disebabkan oleh adanya defisit dalam pembiayaan dan belanja negara.

2. Inflasi yang berasal dari luar negeri (imported inflation), yaitu inflasi yang terjadi karena negara-negara mitra dagang mengalami inflasi yang tinggi, sehingga harga barang dan ongkos produksi di negara tersebut pun menjadi relatif mahal dan mengakibatkan bertambah mahalnya harga jual dari barang yang diimpor dari negara yang dimaksud. 


\section{BI Rate}

Menurut Siamat (2010:139), BI rate adalah suku bunga dengan tenor satu bulan yang diumumkan oleh Bank Indonesia secara berkala untuk jangka waktu tertentu yang berfungsi mensinyalkan kebijakan moneter. BI rate merupakan suku bunga dasar yang diterapkan di Indonesia yang pergerakannya dipergunakan sebagai acuan bagi suku bunga lain, sehingga kenaikan BI rate tersebut akan secara otomatis menyebabkan terjadinya kenaikan pada suku bunga pinjaman. Adapun yang dimaksud dengan suku bunga itu sendiri adalah biaya pinjaman atau harga yang dibayarkan untuk dana pinjaman tersebut (Mishkin, 2010).

Menurut Sunariyah (2011:80), beberapa fungsi tingkat suku bunga dalam perekonomian antara lain adalah sebagai berikut.

1. Sebagai daya tarik bagi penabung individu, institusi, ataupun lembaga yang memiliki kelebihan dana untuk diinvestasikan.

2. Sebagai alat bagi pemerintah dalam mengontrol dana langsung investasi pada berbagai sektor ekonomi.

3. Sebagai alat moneter dalam mengontrol penawaran dan permintaan uang yang beredar.

4. Sebagai alat yang dapat dimanipulasi oleh pemerintah untuk meningkatkan produksi dan mengendalikan tingkat inflasi.

\section{Kurs Rupiah}

Kurs merupakan harga satu unit mata uang asing dalam mata uang domestik atau dapat juga didefinisikan sebagai harga mata uang domestik terhadap mata uang asing (Simorangkir dan Suseno, 2004:4). Adapun Sukirno (2015:397) mendefinisikan nilai tukar atau kurs sebagai perbandingan nilai mata uang suatu negara dengan mata uang negara lainnya.

Sistem kurs yang pernah ada sepanjang sejarah perkembangannya sebagaimana dikutip dari Putong (2013:367), antara lain dijelaskan sebagai berikut.

1. Sistem kurs tetap (fixed exchange rate), yaitu suatu sistem dimana kurs ditetapkan oleh suatu lembaga keuangan internasional ataupun oleh setiap negara dengan disesuaikan oleh kemampuan ekonominya. Sistem ini menetapkan kurs mata uang asing terhadap mata uang domestik dengan nilai yang sama selama periode tertentu.

2. Sistem kurs mengambang (floating exchange rate), yaitu sistem dimana nilai mata 
uang dari suatu negara ditentukan berdasarkan permintaan dan penawaran di pasar uang. Sistem ini terbagi ke dalam dua jenis, yaitu: (a) clean float (mengambang murni), yakni sistem dimana nilai kurs ditentukan dengan tanpa adanya campur tangan pemerintah; dan (b) dirty float (mengambang terkendali), yakni sistem kurs mengambang yang turut serta dikendalikan oleh pemerintah.

3. Sistem kurs terkait (pegged exchange rate), yaitu sistem dimana nilai tukar yang dikaitkan dengan nilai dari mata uang negara lain atau beberapa mata uang tertentu. Apabila kedua sistem kurs di atas adalah nilai kurs /tertinggi terakhir, maka sistem ini mempergunakan nilai kurs tengah dari mata uang tertentu yang mempersyaratkan lebih atau kurang dari kurs tengah sebesar 2,5\%.

\section{Harga Emas Dunia}

Emas merupakan barang berharga yang paling diterima di seluruh dunia setelah mata uang asing dari negara-negara G-7 (sebutan bagi 7 negara dengan perekonomian kuat), yaitu Amerika, Jepang, Jerman, Inggris, Italia, Kanada, dan Perancis. Dalam hal ini, harga emas biasanya akan naik mengikuti kenaikan nilai mata uang dari negara-negara G-7 tersebut. Semakin tinggi kenaikan nilai mata uang asing tersebut, maka semakin tinggi pula harga emas. Kenaikan harga emas bahkan seringkali melebihi kenaikan inflasi itu sendiri (Marsis, 2013:623).

Menurut Sunariyah (2011), logam mulia emas merupakan salah satu bentuk investasi yang cenderung bebas risiko. Dalam hal ini, emas dinilai lebih baik untuk lindung nilai terhadap inflasi. Akan tetapi, hal tersebut dapat berbeda dengan realitanya, karena meskipun dapat menjadi lindung nilai terhadap inflasi dalam jangka panjang, tetapi dalam jangka pendek justru akan mengalami volatilitas harga.

\section{Keterkaitan Antarvariabel Penelitian}

\section{Keterkaitan antara Inflasi dan Indeks Harga Saham}

Tingkat inflasi yang tinggi mencerminkan adanya kenaikan harga barang-barang secara umum yang menyebabkan terjadinya penurunan daya beli. Hal tersebut akan menimbulkan terjadinya penurunan minat investor dalam berinvestasi, sehingga akan menyebabkan harga saham perusahaan mengalami penurunan (Riantani dan Tambunan, 2013). Pendapat tersebut diperkuat oleh hasil penelitian yang dilakukan oleh Ginting, dkk. 
(2016) yang berhasil membuktikan bahwa inflasi berpengaruh negatif dan signifikan terhadap harga saham pada sektor perbankan.

Inflasi yang tinggi juga akan menyebabkan terjadinya penurunan laba perusahaan yang pada akhirnya akan membuat sekuritas perusahaan menjadi kurang kompetitif karena rendahnya daya tarik terhadap investor. Hal tersebut akan mengakibatkan terjadinya penurunan permintaan terhadap sebagian besar saham di pasar, sehingga indeks harga saham di pasar tersebut juga akan mengalami penurunan mengikuti penurunan pada harga dari sebagian besar saham di pasar tersebut.

$\mathrm{H}_{1}$ : Inflasi berpengaruh negatif dan signifikan terhadap indeks harga saham sektor pertambangan di Indonesia.

\section{Keterkaitan antara BI Rate dan Indeks Harga Saham}

Menurut Tandelilin (2010), perubahan BI Rate mampu mempengaruhi indeks harga saham secara terbalik dengan asumsi cateris paribus. Secara teori, kenaikan BI Rate akan membuat suku bunga bank menjadi naik, sehingga menimbulkan terjadinya peralihan dana dari pasar modal ke perbankan. Hal itu terjadi karena kenaikan suku bunga tersebut akan membuat risiko investasi pada produk bank, seperti deposito atau tabungan, menjadi lebih kecil daripada risiko investasi saham. Peralihan sebagian besar dana dari pasar modal ke perbankan tersebut pada akhirnya akan membuat indeks harga saham mengalami penurunan. Sejalan dengan hal tersebut, Jannah dan Nurfauziah (2018) juga berhasil membuktikan adanya pengaruh negatif yang signifikan dari BI rate terhadap indeks harga saham.

$\mathrm{H}_{2}$ : $\quad$ BI rate berpengaruh negatif dan signifikan terhadap indeks harga saham sektor pertambangan di Indonesia.

\section{Keterkaitan antara Kurs Rupiah dan Indeks Harga Saham}

Penurunan besaran rupiah yang harus ditukarkan per satuan dolar AS atau yang dapat diistilahkan sebagai apresiasi rupiah akan membuat perusahaan berbasis ekspor yang bahan bakunya berasal dari dalam negeri menjadi kurang kompetitif dalam persaingan harga. Hal tersebut akan mengakibatkan profitabilitas penurunan, sehingga saham yang bersangkutan akan menjadi kurang menarik di pasar dan harga saham pun akan mengalami penurunan. Oleh sebab itu, pasar yang didominasi oleh perusahaan berbasis ekspor dengan 
bahan baku yang berasal dari dalam negeri justru akan mengalami penurunan indeks harga saham pada saat kurs rupiah terapresiasi.

Hal di atas sejalan dengan hasil penelitian yang dilakukan oleh Jannah dan Nurfauziah (2018) yang menunjukkan bahwa nilai tukar rupiah berpengaruh positif dan signifikan terhadap indeks harga saham. Keduanya menjelaskan bahwa kenaikan besaran rupiah yang harus ditukarkan per satuan dolar AS atau yang dapat diistilahkan sebagai depresiasi nilai tukar rupiah justru akan memperkuat indeks harga saham apabila saham dari perusahaan-perusahaan yang tergabung dalam indeks tersebut didominasi oleh saham perusahaan yang berorientasi ekspor. Dalam hal ini, depresiasi nilai tukar rupiah akan membuat barang ekspor menjadi lebih murah dari perspektif luar negeri sehingga akan menaikkan permintaan dan pada akhirnya menyebabkan terjadinya kenaikan pada indeks harga saham.

$\mathrm{H}_{3}$ : Kurs rupiah berpengaruh positif dan signifikan terhadap indeks harga saham sektor pertambangan di Indonesia.

\section{Keterkaitan antara Harga Emas Dunia dan Indeks Harga Saham}

Emas merupakan salah satu komoditas utama yang ditawarkan oleh perusahaanperusahaan di sektor pertambangan karena bernilai tinggi. Akan tetapi, sifatnya yang tidak dapat diperbaharui berdampak pada terbatasnya penawaran emas. Di sisi lain, permintaan terhadap emas justru terus mengalami peningkatan dari waktu ke waktu karena sifat investasinya yang paling dapat diterima di seluruh dunia setelah mata uang asing dari negara-negara dengan perekonomian kuat, sehingga dinilai cenderung bebas risiko dan dapat menjadi lindung nilai terhadap inflasi dalam jangka panjang. Akibatnya, harga emas dunia juga cenderung mengalami kenaikan dari waktu ke waktu. Kenaikan harga emas dunia tersebut akan menyebabkan naiknya pendapatan dan laba perusahaan pertambangan emas, sehingga akan sekaligus meningkatkan minat investor terhadap saham perusahaan dan pada akhirnya dapat menyebabkan terjadinya kenaikan indeks harga saham pada sektor pertambangan. Pengaruh positif yang signifikan dari harga emas dunia terhadap indeks harga saham ini juga telah berhasil dibuktikan oleh Gumilang, dkk. (2014).

$\mathrm{H}_{4}$ : Harga emas dunia berpengaruh positif dan signifikan terhadap indeks harga saham sektor pertambangan di Indonesia. 


\section{Kerangka Pemikiran}

Kerangka pemikiran dari penelitian ini dapat dilihat pada gambar sebagai berikut.

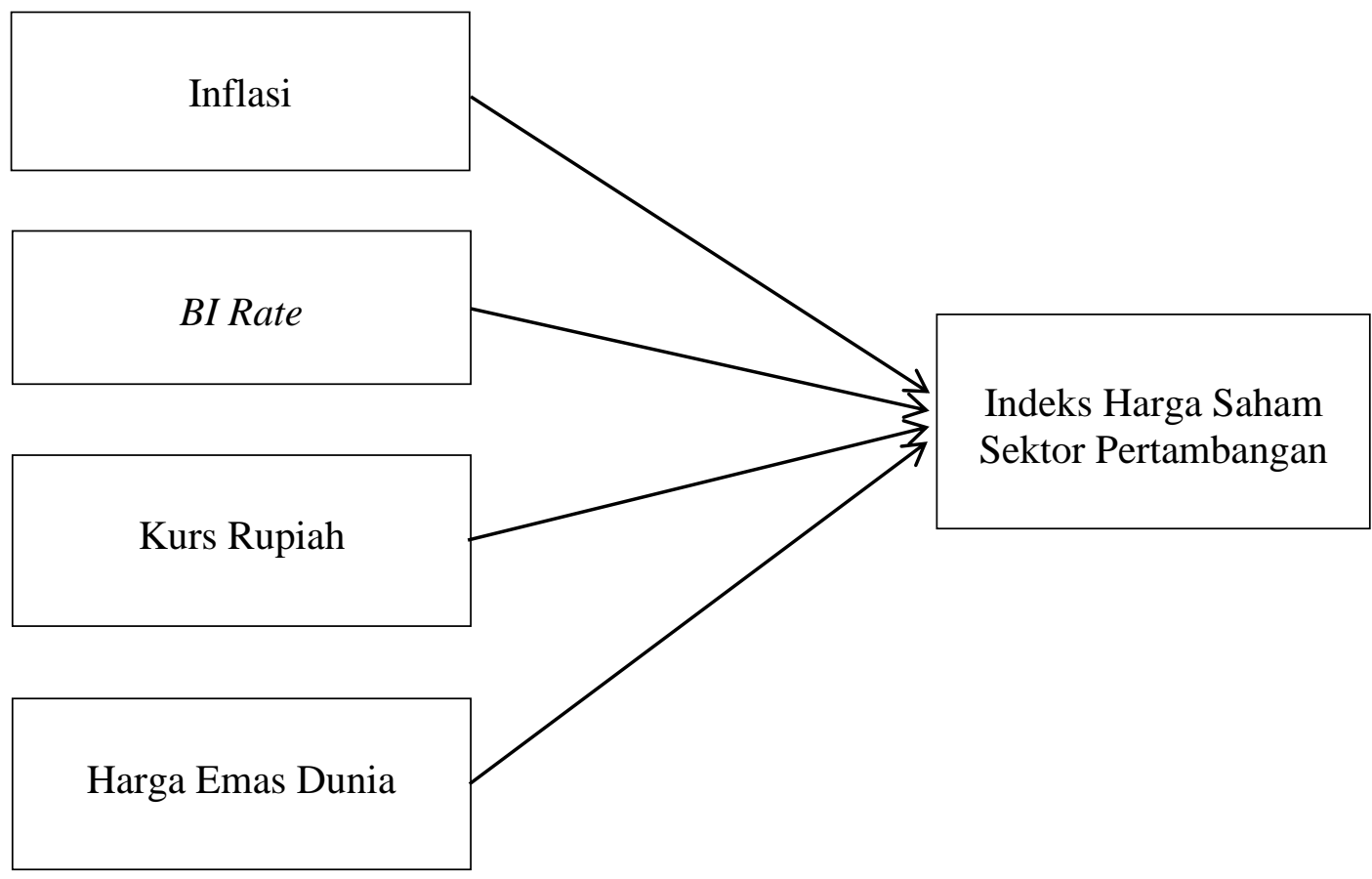

Gambar 2. Kerangka Pemikiran

\section{METODOLOGI PENELITIAN}

\section{Objek Penelitian}

Objek penelitian ini adalah indeks harga saham sektor pertambangan di Bursa Efek Indonesia pada periode 2009- 2015.

\section{Sumber dan Jenis Data}

Penelitian ini menggunakan data sekunder yang berjenis time series. Dalam hal ini, data diperoleh dari website Bursa Efek Indonesia (www.idx.co.id), Bank Indonesia (www.bi.go.id), dan London Bullion Market (www.lbma.org.uk).

\section{Definisi Operasional dan Pengukuran Variabel}

Definisi operasional dan pengukuran variabel dalam penelitian ini dapat dilihat pada tabel sebagai berikut. 
Tabel 1. Definisi Operasional dan Pengukuran Variabel

\begin{tabular}{|c|c|c|c|}
\hline No. & Variabel & Definisi & Pengukuran (Satuan) \\
\hline 1. & $\begin{array}{l}\text { Indeks harga } \\
\text { saham sektor } \\
\text { pertambangan }\end{array}$ & $\begin{array}{l}\text { Indeks harga saham dari seluruh } \\
\text { perusahaan pertambangan yang } \\
\text { terdaftar di Bursa Efek Indonesia. }\end{array}$ & Indeks harga bulanan (poin) \\
\hline 2. & Inflasi & $\begin{array}{l}\text { Kenaikan harga barang-barang } \\
\text { secara umum }\end{array}$ & Inflasi bulanan (\%) \\
\hline 3. & BI rate & $\begin{array}{l}\text { Tingkat suku bunga yang } \\
\text { ditetapkan oleh Bank Indonesia }\end{array}$ & BI rate bulanan $(\%)$ \\
\hline 4. & Kurs rupiah & $\begin{array}{l}\text { Nilai tukar rupiah terhadap dolar } \\
\text { AS }\end{array}$ & $\begin{array}{l}\text { Kurs tengah bulanan } \\
\text { (Rp/USD) }\end{array}$ \\
\hline 5. & $\begin{array}{l}\text { Harga } \\
\text { dunia }\end{array}$ & Harga satuan emas dunia & $\begin{array}{l}\text { Harga emas dunia penutupan } \\
\text { di setiap bulan (USD/troy } \\
\text { ounce) }\end{array}$ \\
\hline
\end{tabular}

\section{Metode Analisis}

Analisis data dilakukan dengan regresi linier berganda menggunakan persamaan sebagai berikut.

$$
\mathbf{Y}=\mathbf{a}+\mathbf{b}_{1} \mathbf{X}_{1}+\mathbf{b}_{2} \mathbf{X}_{2}+\mathbf{b}_{3} \mathbf{X}_{3}+\mathbf{b}_{4} \mathbf{X}_{4}+\mathbf{e}
$$

Keterangan:

$\begin{array}{ll}\mathrm{Y} & : \text { Indeks harga saham sektor pertambangan } \\ \mathrm{a} & : \text { Konstanta } \\ \beta_{1,} \beta_{2,} \beta_{3} & : \text { Koefisien regresi variabel } \mathrm{X}_{1,2,3,4} \\ \mathrm{X}_{1} & : \text { Inflasi } \\ \mathrm{X}_{2} & : \text { BI rate } \\ \mathrm{X}_{3} & : \text { Kurs rupiah } \\ \mathrm{X}_{4} & : \text { Harga emas dunia } \\ \mathrm{e} & : \text { Error }\end{array}$

\section{HASIL DAN PEMBAHASAN}

\section{Hasil Penelitian}

Hasil pengujian asumsi klasik yang dilakukan terhadap data dan model penelitian menunjukkan bahwa data penelitian terbukti terdistribusi normal, sementara model regresi yang digunakan terbukti terbebas dari masalah autokorelasi, heteroskedastisitas, dan multikolinearitas. Setelah memenuhi seluruh persyaratan asumsi klasik tersebut, data kemudian dianalisis dengan menggunakan regresi linear berganda yang dirumuskan dalam 
model persamaan sebagai berikut.

$$
Y=2.921,043+74,096 X_{1}+29,852 X_{2}-0,303 X_{3}+1,1 X_{4}
$$

Keterangan :

$$
\begin{array}{ll}
\mathrm{Y} & =\text { Indeks harga saham sektor pertambangan } \\
\mathrm{X}_{1} & =\text { Inflasi } \\
\mathrm{X}_{2} & =\text { BI rate } \\
\mathrm{X}_{3} & =\text { Kurs Rupiah terhadap US Dollar } \\
\mathrm{X}_{4} & =\text { Harga emas dunia }
\end{array}
$$

Model di atas terbukti layak untuk diteliti karena memiliki nilai signifikansi sebesar 0,000 yang lebih kecil daripada $\alpha$ sebesar 0,05 pada hasil uji F. Hal tersebut sekaligus menunjukkan bahwa inflasi, BI rate, kurs rupiah, dan harga emas dunia secara simultan berpengaruh signifikan terhadap indeks harga saham sektor pertambangan. Sementara itu, besarnya koefisien determinasi dari model penelitian ini adalah 0,688 , sehingga inflasi, $B I$ rate, kurs rupiah, dan harga emas dunia terbukti memberikan kontribusi sebesar $68,8 \%$ dalam menjelaskan indeks harga saham sektor pertambangan, sedangkan 31,2\% lainnya dijelaskan oleh variabel-variabel lain yang tidak dianalisis dalam penelitian ini.

Adapun hasil pengujian hipotesis (uji t) disajikan pada tabel sebagai berikut.

\section{Tabel 2. Hasil Uji t}

\begin{tabular}{|l|c|c|l|}
\hline \multicolumn{1}{|c|}{ Variabel } & t & Sig. & \multicolumn{1}{c|}{ Keterangan } \\
\hline Inflasi & 2,318 & 0,023 & Positif dan signifikan \\
\hline BI rate & 0,277 & 0,783 & Tidak signifikan \\
\hline Kurs rupiah & $-7,235$ & 0,000 & Negatif dan signifikan \\
\hline Harga emas dunia & 4,902 & 0,000 & Positif dan signifikan \\
\hline
\end{tabular}

(Sumber: Data diolah, 2018)

\section{PEMBAHASAN}

\section{Pengaruh Inflasi terhadap Indeks Harga Saham Sektor Pertambangan}

Hasil penelitian ini menunjukkan bahwa inflasi berpengaruh positif dan signifikan terhadap indeks harga saham sektor pertambangan di Indonesia. Artinya, apabila tingkat inflasi mengalami kenaikan, maka indeks harga saham sektor pertambangan di Indonesia juga akan mengalami kenaikan. Sebaliknya, apabila tingkat inflasi mengalami penurunan, maka indeks harga saham sektor pertambangan di Indonesia juga akan mengalami 
penurunan. Hal tersebut sejalan dengan hasil penelitian yang dilakukan oleh Sari (2015) dan Taqiyuddin, dkk. (2012) yang menunjukkan bahwa inflasi berpengaruh positif dan signifikan terhadap indeks harga saham.

Pada saat inflasi berada di angka yang tinggi, saham sebagai salah satu aset nontunai berjenis finansial akan lebih diminati oleh investor karena nilai riil dari return-nya cenderung lebih stabil mengikuti kinerja keuangan perusahaannya daripada aset non-tunai berjenis finansial lainnya seperti deposito dan obligasi yang nilai riil return dari suku bunganya akan tergerus oleh tingkat inflasi. Meskipun pada situasi tersebut bunga deposito dan obligasi kemungkinan besar akan dinaikkan untuk menarik minat investor, nilai riil return-nya tetap saja tidak seberapa jika dibandingkan dengan nilai riil dari return saham pada perusahaan-perusahaan berkinerja baik. Tingginya minat investor terhadap saham akan menyebabkan naiknya permintaan terhadap saham secara umum, sehingga harga indeks saham juga akan naik.

Kenaikan indeks harga saham pada saat terjadinya kenaikan inflasi juga dapat disebabkan oleh strategi manajemen perusahaan untuk meningkatkan modal dan nilai perusahaannya dalam rangka menyiasati pelemahan kinerja perusahaan akibat pembengkakan biaya produksi. Manajemen perusahaan akan mengatur transaksi jual beli saham di antara akun-akun yang berbeda dengan harga jual (offer) dan harga beli (bid) yang tinggi. Artinya, manajemen perusahaan akan menjual sekaligus membeli sahamnya sendiri dengan harga yang tinggi agar permintaan terhadap saham tersebut seolah-seolah terlihat naik. Hal tersebut akan menyebabkan investor lainnya ikut tertarik untuk membeli saham tersebut sebagai bagian dari perilaku herding, yaitu perilaku akibat kondisi psikologis investor yang mengabaikan keyakinan pribadi mereka dan mengikuti keyakinan sebagian besar orang tanpa berpikir panjang (Devenow dan Welch, 1996). Akibatnya, permintaan terhadap saham tersebut akan benar-benar naik, sehingga harga saham tersebut juga akan naik.

\section{Pengaruh BI Rate terhadap Indeks Harga Saham Sektor Pertambangan}

Hasil penelitian ini menunjukkan bahwa $B I$ rate tidak berpengaruh signifikan terhadap indeks harga saham sektor pertambangan di Indonesia. Artinya, kenaikan ataupun penurunan BI rate tidak dapat secara signifikan menimbulkan terjadinya kenaikan ataupun penurunan pada indeks harga saham sektor pertambangan di Indonesia. Hasil 
penelitian ini sejalan dengan hasil penelitian yang dilakukan oleh Wongkar, dkk. (2018) yang menunjukkan bahwa BI rate tidak berpengaruh signifikan terhadap indeks harga saham. Tidak signifikannya pengaruh BI rate terhadap indeks harga saham menunjukkan bahwa terdapat variabel-variabel lainnya yang dapat mempengaruhi indeks harga saham secara lebih signifikan. Dalam kasus ini, inflasi, kurs rupiah dan harga emas dunia terbukti dapat mempengaruhi indeks harga saham secara lebih signifikan daripada BI rate.

Pada umumnya, BI rate tidak dapat secara langsung mempengaruhi indeks harga saham karena kebijakan ini ditujukan untuk mempengaruhi kondisi di pasar uang secara langsung. Kenaikan BI rate diharapkan dapat meningkatkan minat investor untuk berinvestasi di pasar uang. Barulah pengaruh yang diberikan oleh BI rate terhadap pasar uang tersebut diharapkan dapat ikut mempengaruhi pasar modal. Akan tetapi, tidak langsungnya keterkaitan antara BI rate dan indeks harga saham menyebabkan kemampuan BI rate dalam mempengaruhi indeks harga saham menjadi tidak signifikan, terutama jika dibandingkan dengan variabel-variabel lainnya yang dapat secara langsung memberikan pengaruhnya terhadap indeks harga saham.

\section{Pengaruh Kurs Rupiah terhadap Indeks Harga Saham Sektor Pertambangan}

Hasil penelitian ini menunjukkan bahwa kurs rupiah berpengaruh negatif dan signifikan terhadap indeks harga saham sektor pertambangan di Indonesia. Artinya, apabila besaran rupiah yang harus ditukarkan per satuan dolar AS mengalami kenaikan (rupiah terdepresiasi), maka indeks harga saham sektor pertambangan di Indonesia akan mengalami penurunan. Sebaliknya, apabila besaran rupiah yang harus ditukarkan per satuan dolar AS mengalami penurunan (rupiah terapresiasi), maka indeks harga saham sektor pertambangan di Indonesia akan mengalami kenaikan. Hal tersebut sejalan dengan hasil penelitian yang dilakukan oleh Astuti, dkk. (2013) serta Harsono dan Worokinasih (2018) yang menunjukkan bahwa kurs rupiah (Rp/USD) berpengaruh negatif dan signifikan terhadap indeks harga saham.

Harianto dan Sudomo (2001:15) dalam Harsono dan Worokinasih (2018) menjelaskan bahwa pelemahan nilai tukar rupiah terhadap mata uang asing akan menyebabkan terjadinya kenaikan biaya produksi bagi perusahaan yang bahan bakunya diimpor dari luar negeri dengan menggunakan dolar AS dalam transaksi pembeliannya. Kenaikan biaya produksi tersebut akan menyebabkan terjadinya penurunan laba bersih 
perusahaan yang dapat dibagikan kepada para pemegang saham (earnings available for shareholders) melalui dividen. Artinya, kemampuan perusahaan untuk menghasilkan laba dan meningkatkan kesejahteraan para pemegang sahamnya pun mengalami penurunan. Hal tersebut akan menyebabkan terjadinya penurunan minat investor terhadap saham perusahaan, sehingga harga yang bersedia untuk dibayarkan oleh investor untuk memperoleh saham perusahaan pun akan mengalami penurunan. Dalam kasus ini, penurunan harga saham pada sebagian besar perusahaan terbuka di sektor pertambangan di Indonesia pada akhirnya menimbulkan terjadinya penurunan indeks harga saham sektor pertambangan di Bursa Efek Indonesia.

\section{Pengaruh Harga Emas Dunia terhadap Indeks Harga Saham Sektor Pertambangan}

Hasil penelitian ini menunjukkan bahwa harga emas dunia berpengaruh positif dan signifikan terhadap indeks harga saham sektor pertambangan di Indonesia. Artinya, apabila harga emas dunia mengalami kenaikan, maka indeks harga saham sektor pertambangan di Indonesia juga akan mengalami kenaikan. Sebaliknya, apabila harga emas dunia mengalami penurunan, maka indeks harga saham sektor pertambangan di Indonesia juga akan mengalami penurunan. Hal tersebut sejalan dengan hasil penelitian yang dilakukan oleh Gumilang, dkk. (2014) dan Purnamasari (2017) yang menunjukkan bahwa harga emas dunia berpengaruh positif dan signifikan terhadap indeks harga saham.

Emas merupakan salah satu komoditas utama yang ditawarkan oleh perusahaanperusahaan di sektor pertambangan karena bernilai tinggi. Akan tetapi, sifatnya yang tidak dapat diperbaharui berdampak pada terbatasnya penawaran emas. Di sisi lain, permintaan terhadap emas justru terus mengalami peningkatan dari waktu ke waktu karena sifat investasinya yang paling dapat diterima di seluruh dunia setelah mata uang asing dari negara-negara dengan perekonomian kuat, sehingga dinilai cenderung bebas risiko dan dapat menjadi lindung nilai terhadap inflasi dalam jangka panjang. Akibatnya, harga emas dunia juga cenderung mengalami kenaikan dari waktu ke waktu. Oleh karena harga emas di Indonesia juga berkiblat pada harga emas dunia yang ditetapkan di London, maka kenaikan harga emas dunia tersebut akan secara otomatis menyebabkan naiknya pendapatan perusahaan pertambangan emas di Indonesia, sehingga laba perusahaan juga akan mengalami kenaikan. Hal tersebut akan sekaligus meningkatkan minat investor 
terhadap saham perusahaan dan pada akhirnya akan mengakibatkan terjadinya kenaikan indeks harga saham sektor pertambangan di Indonesia

\section{KESIMPULAN DAN SARAN}

\section{Kesimpulan}

Berdasarkan hasil penelitian yang telah dilakukan, maka dapat ditarik kesimpulan sebagai berikut.

1. Inflasi berpengaruh positif dan signifikan terhadap indeks harga saham sektor pertambangan di Indonesia.

2. BI rate tidak berpengaruh signifikan terhadap indeks harga saham sektor pertambangan di Indonesia.

3. Kurs Rupiah berpengaruh negatif dan signifikan terhadap indeks harga saham sektor pertambangan di Indonesia.

4. Harga emas dunia berpengaruh positif dan signifikan terhadap indeks harga saham sektor pertambangan di Indonesia.

\section{Saran}

Berdasarkan hasil penelitian yang telah dilakukan, berikut ini dikemukakan beberapa saran yang dapat dilakukan oleh pihak-pihak terkait.

1. Dalam berinvestasi di pasar modal Indonesia, khususnya pada sektor pertambangan, investor hendaknya senantiasa memperhatikan pergerakan inflasi, kurs rupiah, dan harga emas dunia karena ketiga variabel tersebut terbukti berpengaruh signifikan terhadap pergerakan indeks harga saham sektor pertambangan di Indonesia.

2. Peneliti selanjutnya disarankan dapat menambah variabel makro lainnya yang tidak dijelaskan dalam penelitian ini untuk diteliti pengaruhnya terhadap indeks harga saham.

3. Peneliti selanjutnya disarankan dapat menambah periode pengamatan untuk menganalisis pengaruh jangka panjang dari variabel-variabel makro terhadap indeks harga saham.

4. Peneliti selanjutnya disarankan dapat menganalisis pengaruh berbagai variabel makro terhadap indeks harga saham lainnya yang diakui di Bursa Efek Indonesia. 


\section{DAFTAR PUSTAKA}

Anisa, I. dan A. Darmawan. 2018. Pengaruh Ekonomi Makro dan Harga Komoditas Tambang Dunia terhadap Indeks Harga Saham Sektor Pertambangan di Indonesia. Jurnal Administrasi Bisnis. 56(1): 197-206.

Astuti, R., E.P. Apriatni dan H. Susanta. 2013. Analisis Pengaruh Tingkat Suku Bunga (SBI), Inflasi dan Indeks Bursa Internasional terhadap IHSG: Studi pada IHSG di BEI Periode 2008-2012. Diponegoro Journal of Social and Politic of Science.

Bank Indonesia. 2017. Kurs Transaksi Bank Indonesia. http://www.bi.go.id/id/moneter/ informasi-kurs/transaksi-bi/Default.aspx. 2 September 2017 (14:26).

Boediono. 2013. Ekonomi Moneter. Edisi 3. BPFE. Yogyakarta.

Bursa Efek Indonesia. 2017. Indeks. https://www.idx.co.id/produk/indeks. 29 Agustus 2017 (15:58). 2017. http://www.idx.co.id. 2 September 2017 (10:17).

Cumando, K.E. 2014. Pengaruh Inflasi, Harga Emas Dunia, Harga Minyak Dunia terhadap Harga Saham PT Aneka Tambang Tbk. Skripsi. Program Studi Manajemen Universitas Bengkulu. Bengkulu.

Darmadji, T. dan H. M. Fakhruddin. 2011. Pasar Modal di Indonesia. Edisi Ketiga. Salemba Empat. Jakarta.

Devenow, A. dan I. Welch. 1996. Rational Herding in Financial Economics. Journal of European Economic Review. 40: 603-615.

Ginting, M.R.M., Topowijono, dan S. Sulasmiyati. 2016. Pengaruh Tingkat Suku Bunga, Nilai Tukar dan Inflasi terhadap Harga Saham: Studi pada Sub-Sektor Perbankan di Bursa Efek Indonesia Periode 2011-2015. Jurnal Administrasi Bisnis. 35(2): 77-85.

Gumilang, R.C., R.R. Hidayat dan M.G.W. Endang. 2014. Pengaruh Variabel Makro Ekonomi, Harga Emas dan Harga Minyak Dunia terhadap Indeks Harga Saham Gabungan: Studi pada Bursa Efek Indonesia Periode 2009-2013. Jurnal

Harianto dan Sudomo. 2001. Perangkat dan Analisis Investasi di Pasar Modal Indonesia. PT Bursa Efek Indonesia. Jakarta.

Harsono, A.R. dan S. Worokinasih. 2018. Pengaruh Inflasi, Suku Bunga dan Nilai Tukar Rupiah terhadap Indeks Harga Saham Gabungan: Studi pada Bursa Efek Indonesia Periode 2013-2017. Jurnal Administrasi Bisnis. 60(2): 102-110

Jannah, M. dan Nurfauziah. 2018. Analisis Pengaruh Nilai Tukar Rupiah, Tingkat Suku Bunga SBI dan Harga Emas Dunia terhadap Indeks LQ45 di Bursa Efek Indonesia. Jurnal Manajemen Maranatha. 17(2): 103-110. 
London Bullion Market Association. 2017. Prices and Data. http://www.lbma.org.uk/ pricing-and-statistics. 2 September 2017 (22:26).

Marsis, A.S. 2013. Rahasia Terbesar Investasi. Second Hope. Yogyakarta.

Mishkin, F.S. 2010. Ekonomi Uang, Perbankan, dan Pasar Keuangan. Edisi 8. Buku 1. Salemba Empat. Jakarta.

Purnamasari, D. 2017. Pengaruh Harga Emas Dunia, Harga Minyak Mentah Dunia dan Indeks Produksi Industri terhadap Indeks Saham di Jakarta Islamic Index (JII) dalam Jangka Panjang dan Jangka Pendek Periode Januari 2005 - Desember 2015. Jurnal Ekonomi Syariah Teori dan Terapan. 4(7):515-530.

Putong, I. 2013. Economics: Pengantar Mikro dan Makro. Edisi Kelima. Mitra Wacana Media. Jakarta.

Riantani, S. dan M. Tambunan. 2013. Analisis Pengaruh Variabel Makroekonomi dan Indeks Global terhadap Return Saham. Seminar Nasional Teknologi Informasi dan Komunikasi Terapan 2013. 16 November 2013. Semarang. Hlm. 532-537.

Sari, A.N.P. 2015. Pengaruh Tingkat Inflasi, Suku Bunga SBI dan Nilai Tukar Rupiah pada US Dollar terhadap Pergerakan Indeks Harga Saham Gabungan Perusahaan Manufaktur yang Terdaftar pada Bursa Efek Indonesia Periode Tahun 2010-2013. Skripsi. Program Studi Akuntansi Universitas Dian Nuswantoro. Semarang.

Siamat, D. 2010. Manajemen Lembaga Keuangan. Edisi Keempat. Lembaga Penerbit FE Universitas Indonesia. Jakarta.

Simorangkir, I. dan Suseno. 2004. Sistem dan Kebijakan Nilai Tukar. PPSK. Jakarta.

Sunariyah. 2011. Pengantar Pengetahuan Pasar Modal. Edisi Keenam. UPP STIM YKPN. Yogyakarta.

Sukirno, S. 2015. Teori Pengantar Ekonomi. Edisi 3. RajaGrafindo Persada. Jakarta.

Tandelilin, E. 2010. Analisis Investasi dan Manajemen Portofolio. BPFE. Yogyakarta.

Taqiyuddin, M., T.A. Habsji dan Darminto. 2012. Pengaruh Tingkat Inflasi, Suku Bunga Sertifikat Bank Indonesia dan Nilai Tukar Rupiah pada US Dollar terhadap Pergerakan Indeks Harga Saham Gabungan: Kajian Empiris pada Bursa Efek Indonesia Tahun 2007-2011. Jurnal Profit. 6(2): 15-22.

Wongkar, I.A., S.L. Mandey. H.H.D. Tasik. 2018. Analisis Pengaruh Indikator Makro terhadap Indeks Harga Saham Gabungan di Bursa Efek Indonesia Periode 20112015. Jurnal EMBA. 6(1): 31-40. 